\title{
GIUSEPPE VACCARO: AN "EXPERIMENTER” OF A CONSTRUCTIONAL MODERNITY
}

\author{
ANTONELLO PAGLIUCA, PIER PASQUALE TRAUSI \& DONATO GALLO \\ Dipartimento delle Culture Europee e del Mediterraneo, Università degli Studi della Basilicata, Italy
}

\begin{abstract}
In the first half of the 20th century throughout Europe, on the rubble produced by the two World Wars, new cultural ferments arise as a "critical" response to the socio-political events that affected Europe. In particular, in the Italy of the early 20th century there was a series of changes that affected not only architecture but every aspect of community life. The most important one was the introduction of the industrial process also in the construction sector favoured the search for innovative architectural solutions that led to the definition of a style called 'Modern': architecture must communicate clarity and knowledge, in order to achieve greater utility through the use of materials and construction systems to combine beauty and functionality of the building (see B. Taut). In the wide panorama of the most important figures of Modern Italian architects, the architect Giuseppe Vaccaro distinguished himself particularly in his different (often daring) architectural experiments for the ability to combine the typical instances of the typically Italian construction tradition with the new avantgardes constructive and technological of the beginning of the century. In fact, different times Giuseppe Vaccaro was collaborator of architect Marcello Piacentini and forefather of Modern architectural culture in Italy, he was the author, in particular, of one of the most important buildings of the Modern: the "Palazzo delle Poste" in Napoli. The building, designed together with Gino Franzi between 1933-1936, is close by the ancient Cloister of Monteoliveto; in particular, the main façade, articulated along a hyperbolic line, becomes an occasion for architectural and urban renewal of the district of Charity, in the centre of Napoli. The monolithic nature of this architecture and the typological, technological, constructive and of material characteristics become an instrument through which the architect tells of a "new Italy" that experiments innovations and avant-gardes of materials and constructive aspects, as result of experiments of Italian industries of the early 20th century. The research, part of a broader study of 20thcentury architecture, emphasizes, therefore, the need for a historical-analytical cognitive approach as a tool for the conservation the importance of each "value" of these architectures as an expression of a "Made in Italy" style.
\end{abstract}

Keywords: '900 architecture, construction, technological characterization, modern movement.

\section{INTRODUCTION AND METHODOLODY}

In Italy the 20th century was a period in which the industrial processes contributed to the creation of a new architectural type. This period, in fact, constitutes one of the most interesting phase in the cultural and architectural Italian history. Today, after more than a century, these buildings represent an historical heritage to be preserved and protected.

Therefore, these architectures today constitute a very "fragile" heritage and an in-depth knowledge is required to design their recovery.

Therefore it is important to know:

- the typological aspects (which are the evolution of the classical compositional theory);

- the social aspects (in particular the collaboration between industry and architecture for the realization of building components); and

- aspects related to materials and construction techniques (the technological elements represent an experimental idea of the Modern culture of the 20th century, contributing to create a new housing idea and social types). 
In order to plan a recovery intervention, therefore, it is necessary to analyze the archive documentation ("indirect" sources) and realize a survey on site ("direct" sources), in order to increase the level of knowledge on the architectures, especially regarding the technological and construction aspects and the materials characterization.

Through the analysis of a case study of rationalist architecture (the "Palazzo delle Poste e dei Telegrafi" in Naples, designed by the architects Giuseppe Vaccaro and Gino Franzi), the research aims to experiment a methodology that starting from the above said analysis sources (i.e. technical manuals, brochures of industrial products, architecture and engineering journals), examining the detail of materials, the construction systems, led up to the creation of an "axonometric section," as a useful instrument to analyze the relationship between architecture and constructional system.

\section{RATIONALISM IN ARCHITECTURE}

In the first half of the 20th century, the South Italy was involved in a "restructuring project" carried out by the Government to create the image of a "new Italy" [1]. In fact, in 1925 the Government gave an important sign of relaunching the economy of different cities; among them Naples, one of the most important centers in the South; there, the Liberty modernism was soon supplanted by monumentalism carried out by the group of Gustavo Giovannoni, in particular by some Neapolitan academics such as Roberto Pane, Marcello Canino, Camillo Guerra, etc. [2].

Thus, Neapolitan architecture begins to share the directives of the group of "academic architects," who work according to the canons of classical architecture, which already characterized the historic city of Naples [3].

A series of urban interventions and buildings are designed that change the layout of some parts of the city, as the demolition of a stratified area in the district "Carità." Here a new political and financial center was built with a series of important institutional buildings, such as the "Regia Questura," the "Casa del Mutilato," the "Palazzo della Provincia" and the "Palazzo delle Poste e dei Telegrafi." This last building was the subject of a competition announcement that was won (after a series of variations) by Giuseppe Vaccaro and Gino Franzi. Compared to the headquarters of the Banco di Napoli (in the nearby via Toledo), built between 1936 and 1939 by Marcello Piacentini, the "Palazzo delle Poste" has a very interesting architectural quality, closer to rationalism than to neoclassical monumentalism.

For the architects was difficult to design the building in an interclosed space in the historic center; in fact, the neighboring architectures limited the project by imposing the plan (irregular), the height of the building (equal to surrounding ones) and the inclusion in the project of a Renaissance loggia [4].

The complexity of the building is highlighted in the formal choice but also in the technological and constructive ones, with the inclusion of a stone cladding system that attempts to clarify the troubled "question of stone cladding envelope" [5], through the study of different types of anchors that create a new formal idea of buildings.

"A first sketch of the façade, designed with impetus in a moment of disheveled inspiration, was then completely revised, checked, strengthened and this building, which even had the daring and imagination of the architect, but which fell ahead of an examination of environmental values, has turned into a healthy and environmental form. And no less Modern for this reason: indeed, precisely for this reason, more Modern than ever" [6]. 


\section{GIUSEPPE VACCARO:}

\section{THE "PALAZZO DELLE POSTE E TELEGRAFI" IN NAPOLI}

The "Palazzo delle Poste e dei Telegrafi" takes up the concept of "artwork" applied to Italian rationalism buildings that aims at defining every detail at different scales, from the architectural one to the interior design one, with a refined control of finishes and materials.

The envelope cladding is entirely realized in marble (taking up the formalism of the Roman academic school) while the semicircular staircase and the central pillar (located in the center of the monumental entrance) are realized in black granite (called "Diorite") and gray marble caming from Valle Strona.

Particularly interesting is the line that characterizes the external elevation, a hyperbola with maximum curvature at the center; it allows to solve the design problem at the corners and to emphasize the external entrance to the building. This building represents the right compromise between the rational-avant-garde instinct and the academic obligations imposed by the Regime.

The "Palazzo delle Poste e dei Telegrafi," in fact, became an important reference for modernity, also published in the same architectural magazine called "Architettura" directed, at that time, by Marcello Piacentini; he also was the coordinator of the Faculty of Architecture in Rome after Gustavo Giovannoni.

\subsection{Construction and industry}

The architect Giuseppe Vaccaro distinguished himself for his various architectural experiments and for his ability to combine the demands of the construction tradition with the new construction and technological avant-gardes of 20th century.

The "Palazzo delle Poste e dei Telegrafi," in fact, collects numerous constructive instances of the Modern that are inserted in the (growing) Italian building industry and that leads to a renewed "construction culture" and new stylistic experiments, innovative materials and the coding of construction technologies more suitable for general trend of "machine civilization" [7].

\subsubsection{Main and secondary structure}

The structure, designed by Eng. Francesco Fiacchi, is made of reinforced concrete with "multiple frames" resting on a foundation realized with a slab of reinforced concrete $(50 \mathrm{~cm}$ thick) and stiffening beams $(1 \mathrm{~m} \times 2 \mathrm{~m}$ in section) (Fig. 1). The foundation is divided into ten elements by expansion joints, on which the pillars of the "Mannesmann" typology weigh down; those pillars were made with the "beton frétte" technique which involved the confinement in the pillar of a helical reinforcement, capable of significantly increasing the resistance to compression of the column.

The masonries are realized in perforated brick for the internal partitions and solid bricks for the external envelope. In addition, there are also masonries realized using the glass block technique to ensure the lighting of internal rooms.

The floors are a solid slab type in reinforced concrete and of the mixed type concretebrick, as well.

The false ceilings are made with the construction system of the "Graticcio Stauss," a flexible mat "consisting of an orthogonal mesh of $20 \mathrm{~mm}$ on each side made with iron wire (diameter $1 \mathrm{~mm}$ ) which at the intersection has polyhedral clay crosses, cooked at high temperature with a special process" [8]. The mat is easily adaptable to any flat or curved geometric surface and provides excellent support for the subsequent plastering phase. 


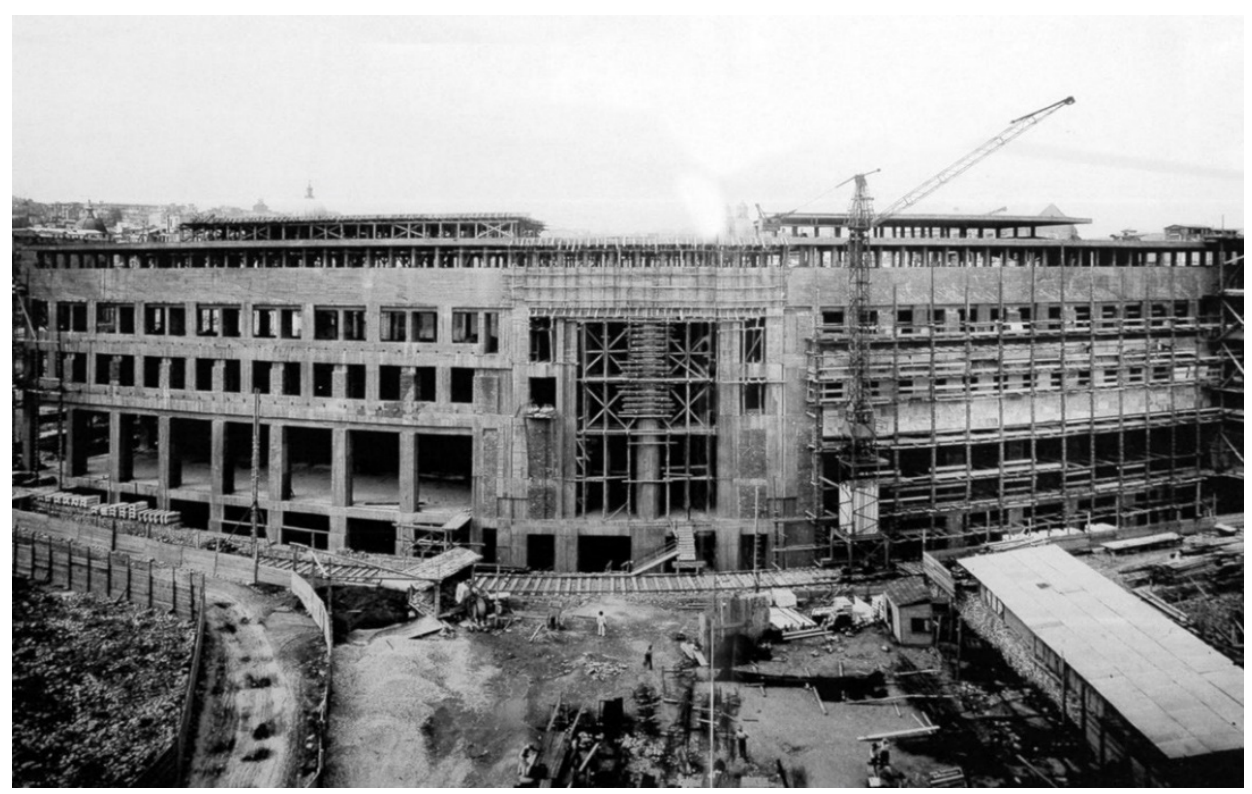

Figure 1: Historical image of building site. (Source: Archivio Giuseppe Vaccaro.)

\subsubsection{Envelope system}

The above said iconic hyperbolic shape of façade of "Palazzo delle Poste e dei Telegrafi" represents one of the most interesting part of design of stone cladding envelope, realized (as said before) in reinforced concrete and with an innovative technological systems (with the experimentation of the new system of thin coatings in stone elements). The cladding materials are: black diorite called "Baveno" (cladding in $5 \mathrm{~cm}$ thick sheets) for the lower part of the façade and the central pillars; marble called "Vallestrona" (cladding in $3 \mathrm{~cm}$ thick slabs) for the remaining part of the façade (Fig. 2). "The façade is not intended as a delimitation surface between external and internal architecture: the first is the natural continuation of the second" [9].

The windows are realized in stainless steel (produced by the Bombelli Company of Milan and installed by the Cassinelli \& Guercini Company of Rome) whose execution is "of exceptional preciousness both in the up and down gates that characterize the façade and in the large glass walls, made up of from 38 large unbreakable slabs $4.50 \mathrm{~m}$ wide, $75 \mathrm{~cm}$ high and $1 \mathrm{~cm}$ thick, framed by a metal structure; the vertical uprights are invisible because they are embedded in the marble" (Fig. 3) [10].

\subsubsection{Coatings and finishes}

The interior is also embellished with marbles such as that called "Rosso Monte Amiata," "Vitulano" marble, "Bellona" stone, "Trani" and "Verde del Brennero" stone.

The stone materials, worked by local artisans, are combined with ceramic and glassy artificial materials, coming from the wise Italian experimental ingenuity and synonymous of constructive progress and industrialization of production processes.

Some of them are the "Desagnat" and the "Fontanit" (both produced by the Società Anonima Luigi Fontana of Milan) that are applied in the form of mosaic tiles for covering large surfaces [11]. 


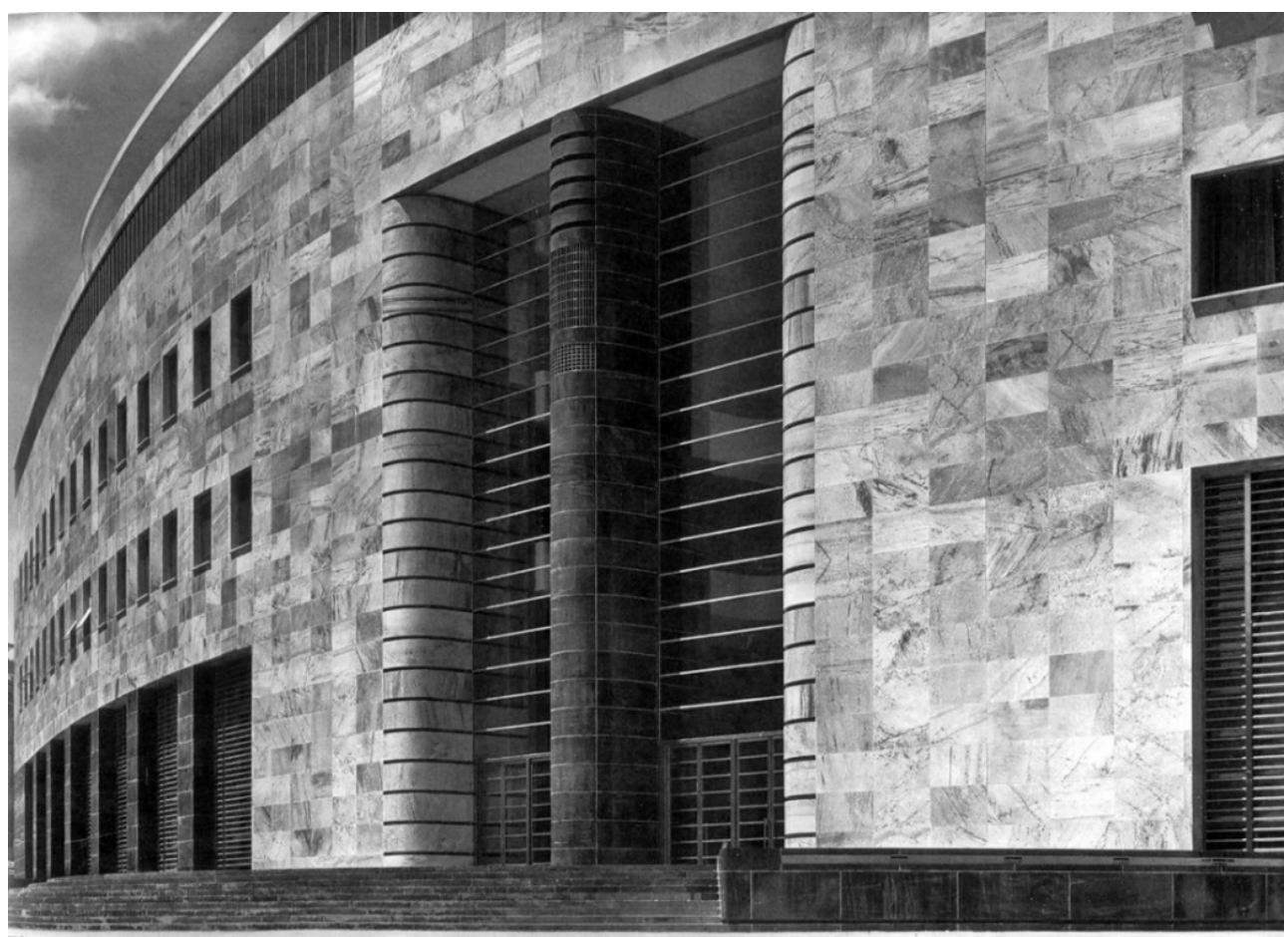

Figure 2: Historical image of stone cladding envelope of façade. (Source: Archivio Giuseppe Vaccaro.)
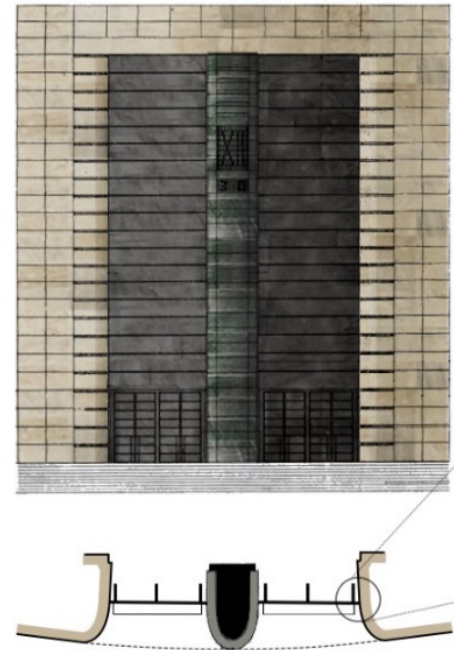
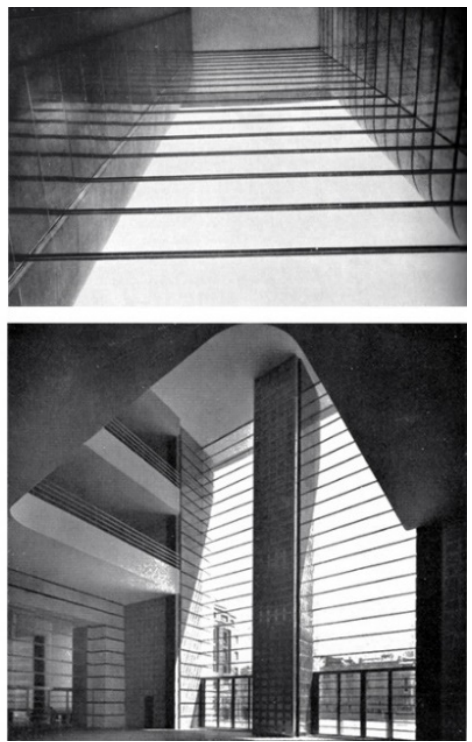

Figure 3: Stainless steel windows with the vertical uprights (details). 
The "Desagnat," in particular, is "made up of colored glass mosaic tiles crossed in the two orthogonal directions by hollows forming many small mosaic tiles joined to a support of highly resistant fabric mat" [8], [12] and used to embellish the entrance shelter [13] (Fig. 4).
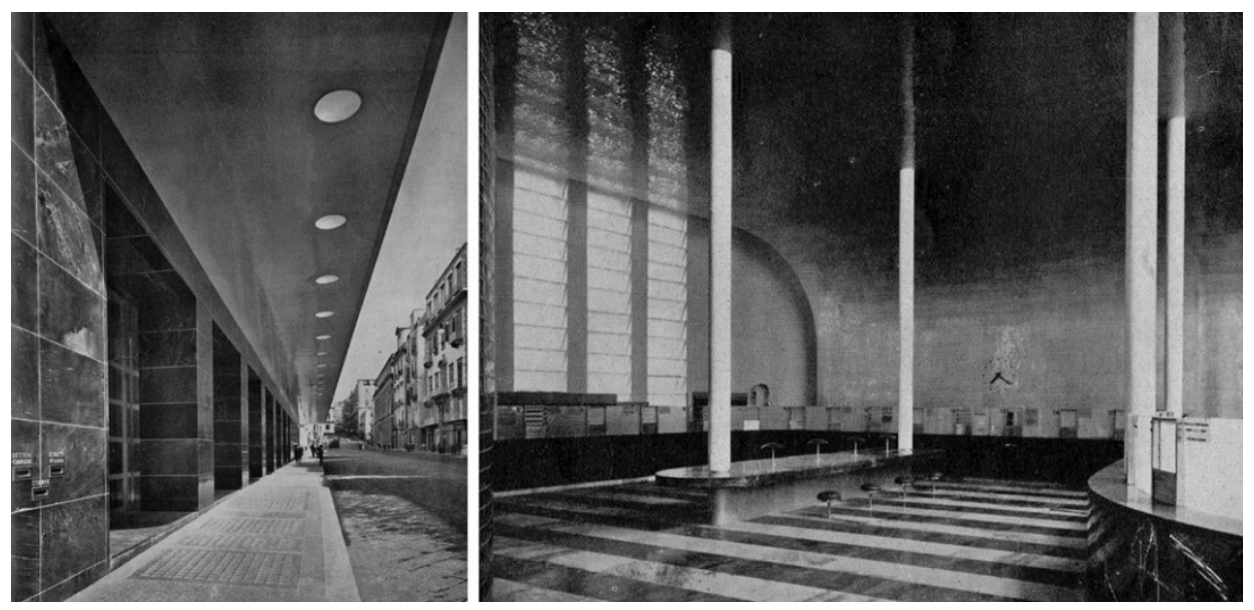

Figure 4: Detail of the shelter covered in "Desagnat" glass with (on the left) and the hall (on the right) with the vaulted surface in "Desagnat" glass and the "Mannesmann" columns also covered in "Desagnat" glass. (Source: "Architettura: rivista del Sindacato Nazionale Fascista Architetti".)

There are several applications of reinforced glass blocks, too; they constitute a very widespread construction system in Italian rationalist architecture through the marketing of numerous diffusers designed by the "Società Anonima of Saint Gobain, Chauny and Cirey."

In fact, there are numerous types of diffusers (Nevada, Novalux, Prismalith, Duralux, Clarilux, Cupolux, Discolith, Isocalor, Luxfer, Opalina, Planilux, Quadralith, etc.) also used in the Palazzo delle Poste and Telegrafi, especially in the envelope (i.e. entrance vestibule, the cylindrical glass block wall of boardroom) [14] (Fig. 5).

The flooring are realized using precious glassy mosaic, marble (in the reception rooms) and Linoleum with different colors (brown, blue, black marble effect, dark gray, Pompeian red, etc.) in all offices, corridors and wainscots (Fig. 6).

Finally, as regards the architraves and window jambs are finished with white calcium stucco, while the cantilever roof roofing (with reinforced concrete structure) has the external finish with plaster called "Duralbo" "produced by the "Società Istriana dei Cementi" which represents the only artificial Portland cement manufactured in Italy and obtained from the "clinkerization" process of kaolin, marl in special rotary kilns" [8].

\subsubsection{The technological equipment}

"The central heating system is based on radiators, with partial application of convectors and heating system by air. The building is equipped with pneumatic post systems, mechanical belt conveyors for posting (the letters set arrive directly on the sorting tables), a system of belt conveyors and clamps in the room of telegraph equipment, electric clocks to central command in main offices" [9]. This set of systems, with attention to every detail, even from an aesthetic point of view, constitutes the most complete and new idea implemented in the growing Modern architecture. 

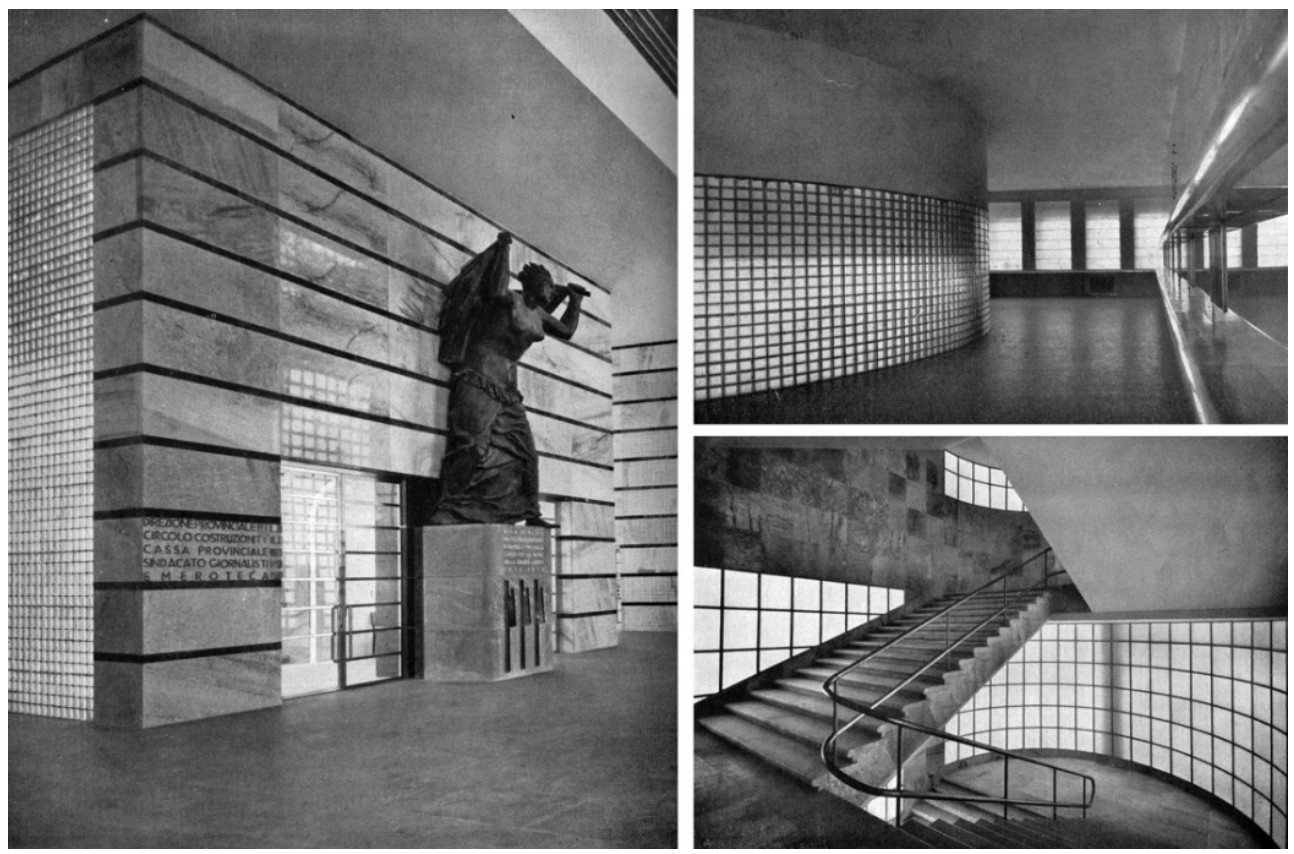

Figure 5: Detail of the walls made using the reinforced glass block construction system in the entrance vestibule (on the left), of the Provincial Bank room (above, on the right) and of the staircase enclosed in the cylindrical glass block wall (below, on the right). (Source: Architettura: rivista del Sindacato Nazionale Fascista Architetti.)
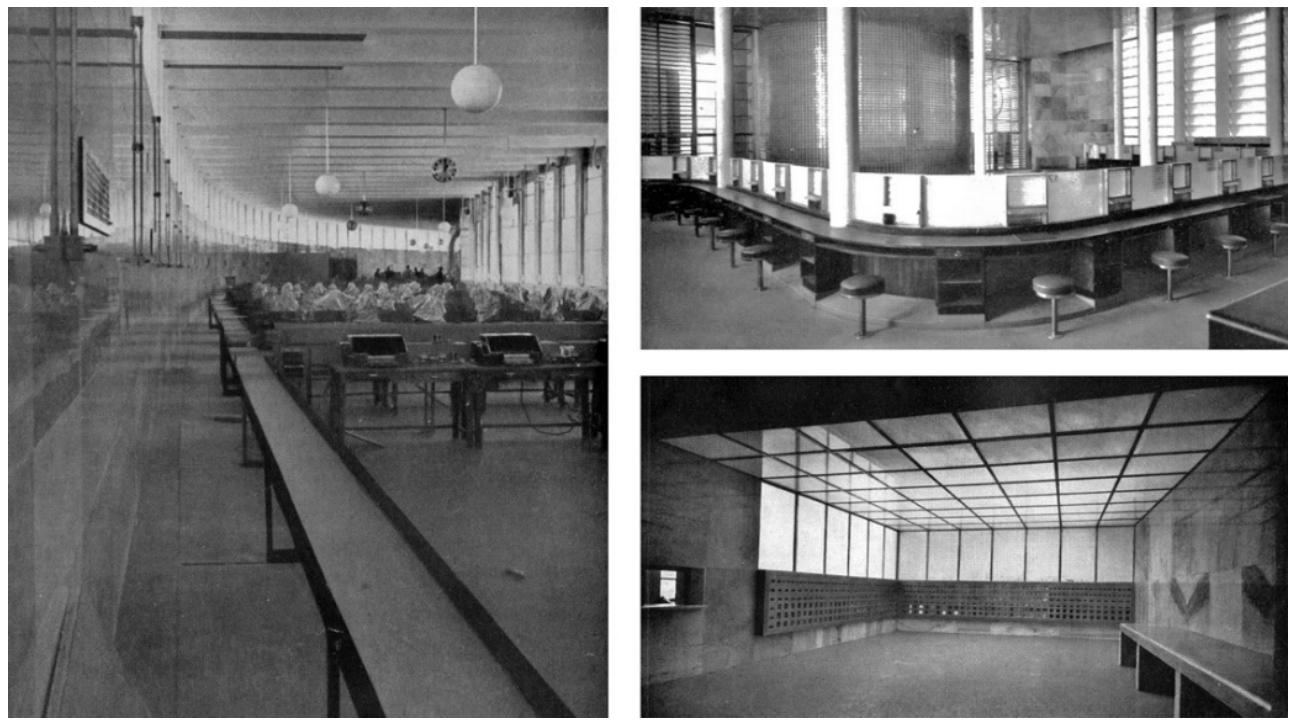

Figure 6: The floorings in Linoleum (details). 


\subsubsection{Interior design}

Most important is also the elegant interior design, studied by the designers down to the smallest detail with a careful choice of both traditional and innovative materials (i.e. Albes, Buxus, etc.) which undoubtedly contribute to confer nobility to the simple architectural volumes, transformed them in a "monumental expression," where "no superfluous elements and no excessive dimensions have been adopted to render this expression rhetorical, which instead it was entrusted only to the unitary composition of the elements and, therefore, of the forms, and to the expressive value of the relationships" (Fig. 7) [9].
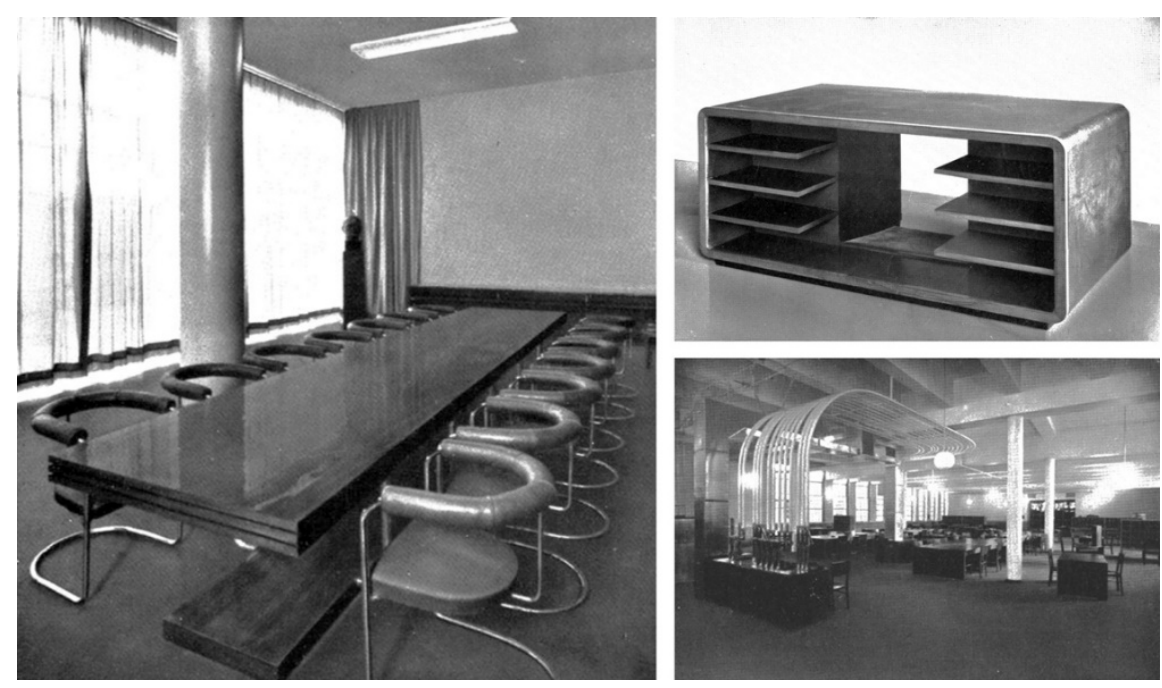

Figure 7: Interior design elements realized with traditional and innovative materials.

\section{CONCLUSIONS}

This building, like others built in the same period, represent a very "fragile" heritage [15]. To operate a recovery intervention on these buildings is necessary to know all its architectural, technological and constructive elements [16].

As for G. Vaccaro's building, many other architectures hide much more innovative construction systems behind natural stone claddings envelopes.

In fact, it's enough to analyze the structure framed in reinforced concrete (with the innovative "Mannesmann" columns), the experimental use of the anchoring system of the cladding in very thin solid marble and the new materials made in Italy.

All these elements have contributed to transform and change the Italian cultural trend and its traditional building practice.

The "Palazzo delle Poste e dei Telegrafi" - as said above - a monument of Italian Rationalism, represents one "of the first significant episodes in the context of a construction problem that would have assumed considerable importance in the history of Modern construction in Italy" [17].

Through the analysis of this case study, therefore, it is possible to highlight that the knowledge of technology and construction systems is crucial for a suitable design of recovery interventions. In the same way, the used system of the "axonometric section" (Fig. 8) is a useful tool for the designer and technician as it allows to show, using a single drawing, the relationship between technique and architecture. This system of representation highlights the 
technological innovation of these structures, otherwise hidden behind envelope materials (i.e. natural stone, bricks, etc.), too; this approach allows to plan recovery interventions on this cultural heritage, through a "scientifically correct" method of knowledge and representation [18].

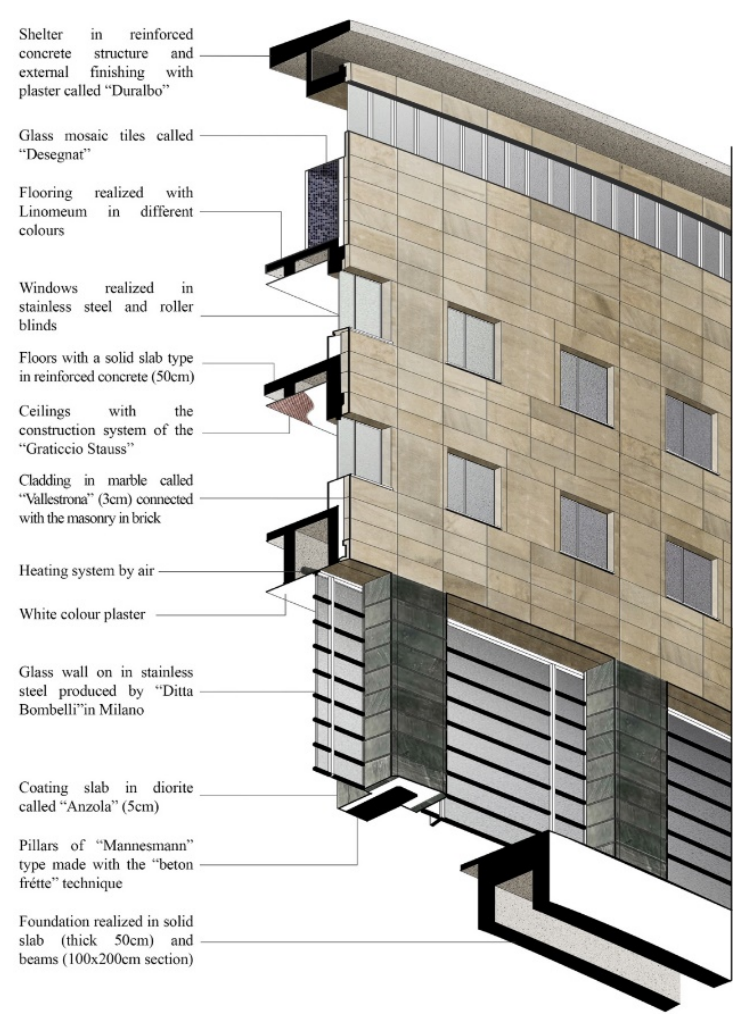

Figure 8: Information model of Palazzo delle Poste e Telegrafi in Napoli.

\section{REFERENCES}

[1] De Seta, C., La civiltà architettonica in Italia. 1900-1944 arte e architettura, Clean: Napoli, 2019.

[2] Frampton, K., Storia dell'architettura moderna, Zanichelli: Bologna, 1982.

[3] Ciucci, G. \& Muratore, G., Storia dell'Architettura Italiana. Il Primo Novecento, Electa: Roma, 2004.

[4] Cislaghi, P., Il rione Carità, Electa: Napoli, 1998.

[5] Poretti, S., Modernismi Italiani. Architettura e costruzione nel Novecento, Gangemi: Roma, p. 24, 2008.

[6] Opere di Giuseppe Vaccaro. Architettura. Rivista del Sindacato Nazionale Fascista Architetti, Fascicolo X: Milano, 1932.

[7] Gallo, D., Modernità italiana nel sistema involucro. Quaderni di tecnologia dell'architettura. Sistemi tecnologici e costruttivi del "Movimento Moderno", ed. A. Pagliuca, Favia: Bari, pp. 10-11, 2020. 
PI-14 Structural Studies, Repairs and Maintenance of Heritage Architecture XVII

[8] Pagliuca, A., Materiali Made in Italy: Avanguardia Italiana nell'Industria delle Costruzioni del Primo '900, Gangemi: Roma, pp. 525-541, 2019.

[9] Vaccaro, G., Edificio per le Poste e Telegrafi di Napoli. Architettura. Rivista del Sindacato Nazionale Fascista Architetti, vol. 8, Fascicolo VIII: Milano, pp. 353-391, 1936.

[10] Vitellozzi, A., Il nuovo Palazzo postale di Napoli. Periodico trimetrale "Edilizia Moderna”, vol. 23, Milano, pp. 1-9, 1936.

[11] Griffini, E., La Costruzione Razionale della Casa, IV Edizione, Hoepli: Milano, 1948.

[12] Zorzi, L., Intonachi, Pavimenti, Rivestimenti Nella Moderna Edilizia, Edizioni Tecniche Utilitarie: Bologna, p. 167, 1935.

[13] Griffini, E., Costruzione Razionale della Casa - I nuovi materiali, Hoepli: Milano, 1932.

[14] Dal Falco, F., Stili del Razionalismo, Anatomia di Quattordici Opere di Architettura, Gangemi Editori, 2002.

[15] Iori, T., Il Cemento Armato in Italia, Dalle Origini Alla Seconda Guerra Mondiale, Edilstampa: Roma, 2001.

[16] Carbonara, G., Il restauro del moderno. Trattato di Restauro Architettonico, UTET: Torino, 1996.

[17] Poretti, S., La facciata del Palazzo delle Poste di Napoli e la questione dei rivestimenti lapidei nell'architettura italiana negli anni trenta. Architettura e Costruzione, nn. 8485 , pp. $28-37$.

[18] Poretti S., Modernismi Italiani. Architettura e Costruzione nel Novecento, Gangemi: Roma, p. 24, 2008. 